\section{PENGATURAN HUKUM INTERNASIONAL TENTANG PERLINDUNGAN PEJABAT DIPLOMATIK DI NEGARA PENERIMA ${ }^{1}$}

Oleh: Gracia E. Siregar ${ }^{2}$

\begin{abstract}
ABSTRAK
Tujuan dilakukannya penelitian ini yaitu untuk mengetahui bagaimana Pengaturan hukum internasional tentang Perlindungan Pejabat Diplomatik di Negara Penerima dan bagaimana Pertanggungjawaban Negara terhadap Pejabat Diplomatik yang mendapat ancaman di Negara Penerima di mana dengabn metode penelitian hukum normatif disimpulkan: 1. Pelanggaran terhadap pejabat diplomatik sangat marak terjadi, baik itu ancaman maupun terorisme. Padahal, para pejabat diplomatik mempunyai tugas yang sangat berat dalam hal menjalin hubungan dan menjadi perwakilan bagi negaranya di negara penerima. Untuk itu diperlukan sebuah instrumen hukum sebagai bentuk perlindungan terhadap para perwakilan diplomatik di negara penerima. Dalam hukum internasional pun telah mengatur adanya aturan-aturan berupa konvensi tentang perlindungan terhadap perwakilan diplomatik maupun konsuler. Konvensi-konvensi tersebut yaitu, Konvensi Wina 1961 tentang Hubungan Diplomatik dan Konvensi Wina 1963 tentang Hubungan Konsuler. Dalam konvensi-konvensi tersebut telah berisi tentang bagaimana hak kekebalan dan keistimewaan dari perwakilan diplomatik dan konsuler itu sendiri. 2. Sebagai negara penerima memiliki kewajiban untuk menjamin adanya keselamatan dan serta melindungi para perwakilan diplomatik di negaranya, sesuai dengan yang telah tercantum dalam Konvensi Wina Pasal 29. Namun jika terjadi pelanggaran atau ancaman terhadap perwakilan diplomatik di negara penerima, sebagai Negara penerima harusnya bertanggungjawab penuh atas pelanggaran yang terjadi terhadap para pejabat diplomatik di negaranya. Dan bentuk tanggung jawab terhadap pelanggaran yang terjadi dapat dilihat sesuai dengan Draft ILC 2001 yaitu, Reparation (perbaikan), Compensation (kompensasi),
\end{abstract}

\footnotetext{
${ }^{1}$ Artikel Skripsi. Dosen Pembimbing: Hengky A. Korompis, $\mathrm{SH}, \mathrm{MH}$; Marthim N. Tooy, SH,MH

2 Mahasiswa pada Fakultas Hukum Unsrat, NIM. 16071101520
}

Restitution (restitusi) dan Satisfaction (pemuasaan).

Kata kunci: pejabat diplomatik;

\section{PENDAHULUAN}

\section{A. Latar Belakang}

Perwakilan Diplomatik merupakan Petugas Negara yang dikirim pada Negara lain untuk melaksanakan hubungan resmi antar Negara. Berdasarkan Konvensi Wina 1961 fungsi pejabat diplomatik adalah untuk mewakili suatu Negara yang mengirim pada Negara penerima, melindungi kepentingan Negara penerima dan warga negaranya di Negara penerima tersebut, membuat persetujuan dengan Negara penerima, sesuai dengan undang-undang dan membuat laporan kepada pemerintah Negara pengirim, serta menjaga hubungan baik antara Negara penerima dan Negara pengirim.

\section{B. Perumusan Masalah}

1. Bagaimana Pengaturan hukum internasional tentang Perlindungan Pejabat Diplomatik di Negara Penerima?

2. Bagaimana Pertanggungjawaban Negara terhadap Pejabat Diplomatik yang mendapat ancaman di Negara Penerima ?

\section{Metode Penulisan}

Metode pendekatan yang digunakan dalam penelitian ini adalah yuridis normative.

\section{PEMBAHASAN}

A. Pengaturan Hukum Internasional tentang Perlindungan Pejabat Diplomatik

Para pejabat diplomatik yang menjalankan tugas di suatu negara berada dalam suatu situasi yang khusus. Misi diplomatik tersebut merupakan sarana negara pengirim dalam melakukan tugas-tugas resmi di negara penerima. $^{3}$ Tetapi seringkali hubungan diplomatik yang dilakukan antar negara ditandai dengan tindakan-tindakan tidak mengenakan satu sama lain seperti penculikan, pembunuhan, serangan terhadap pejabatpejabat diplomatik maupun perwakilan diplomatik (gedung perwakilan dan tempat tinggal) dan juga gangguan terhadap misi-misi diplomatik. Dalam beberapa hal diplomat dijadikan sasaran karena statusnya sebagai

\footnotetext{
${ }^{3}$ Boer Mauna, Op. Cit., 502.
} 
wakil dari negara-negara dengan kebijakankebijakan tertentu atau sebagai tekanan terhadap pemerintah untuk mencapai tujuantujuan politik tertentu ataupun juga untuk merusakkan kredibilitas pemerintah yang sah. ${ }^{4}$

Pelanggaran terhadap hak-hak kekebalan dan keistimewaan perwakilan diplomatik sangat marak terjadi di dalam tahun 1980-an, laju kegiatan tindak terorisme cukup menonjol khususnya yang dilakukan terhadap para pejabat diplomat merupakan tindakan yang sangat membahayakan fungsi mereka dalam melakukan tugas sehari-hari. Dalam tahun 1980, tercatat ada 400 tindak terorisme yang ditujukan kepada para pejabat diplomatik dan konsuler yang meliputi 60 negara. Sedangkan selama 6 bulan pertama dalam tahun 1981, terdapat 191 tindak terorisme dengan objek yang sama termasuk yang menyangkut perwakilan atau misi asing. ${ }^{5}$

Sebagai contoh, kasus penembakan Duta Besar Rusia, Andrei Karlov pada 19 Desember 2016 di Ankara Turki. Kejadian terjadi di sebuah acara seni yang dilaksanakan oleh pemerintah Rusia, disana Andrei Karlov memberikan pidato. Penembakan kemudian dilakukan oleh seorang mantan polisi Turki yaitu Mevlut Mert Atlintas. Andrei Karlov meninggal di rumah sakit saat diberikan perawatan. ${ }^{6}$ Dari kejadian tersebut, Duta Besar Rusia sedang melaksanakan fungsi diplomatik, sehingga telah terjadi adanya pelanggaran terhadap hak kekebalan dan istimewa perwakilan diplomatik.

Kemudian ada contoh yang berikutnya, kasus penyadapan di kantor Kedutaan Besar Republik Indonesia (KBRI) yaitu terjadi di Korea Selatan, Kanada, Jepang, Finlandia, Norwegia, Denmark, China, dan Myanmar. Untuk di Myanmar, kasus penyadapan terjadi dua kali yaitu pada 2003 dan 2004. Dikarenakan kasus tersebut, maka tim gabungan keamanan Republik Indonesia yang terdiri dari unsur Lembaga Sandi Negara (Lemsaneg), Badan Intelijen Negara (BIN) dan Departemen Luar Negeri melakukan pemeriksaan di Kantor KBRI Yangon, Myanmar. Pemeriksaan tersebut menunjukan bawah junta militer Myanmar

\footnotetext{
${ }^{4}$ Ibid. hlm 504.

${ }^{5}$ Sumaryo Suryokusumo, Op. Cit. hlm 33.

6 "Duta Besar Rusia untuk Turki tewas di Ankara" https://www.bbc.com/indonesia/dunia-38373034, diakses pada 11 september 2019
}

secara ilegal menyadap semua aktivitas dan pembicaraan para diplomat Republik Indonesia yang bertugas di Yangoon, Myanmar dengan memasang alat penyadap pada dinding kamar kerja Duta Besar Republik Indonesia untuk Myanmar. ${ }^{7}$ Disini peran pemerintah Myanmar sebagai negara penerima harusnya ikut mengamankan dan melindungi hak kekebalan dan keistimewaan perwakilan diplomatik termasuk gedung perwakilan, tetapi nyatanya dari pemerintah Myanmar malah melanggar hak kekebalan dan keistimewaan diplomatik.

Seiring dengan banyaknya pelanggaran terhadap hak kekebalan dan keistimewaan dari perwakilan diplomatik. Maka dari itu dibuatnya Konvensi yang mengatur adanya perlindungan terhadap para perwakilan diplomatik daripada serangan dan ancaman yang terjadi, yaitu :

\section{Konvensi Wina 1961 tentang Hubungan Diplomatik}

Kewajiban internasional untuk melindungi para pejabat diplomatik dan konsuler termasuk gedung perwakilannya masing-masing merupakan hal yang mutlak dilakukan oleh semua negara anggota, apalagi telah diberlakukannya beberapa instrumen internasional tentang hal itu.

Dalam Konvensi Wina 1961 Pasal 29 mengatur bahwa : "The person of a diplomatic agent shall be inviolable. The receiving state shall treat him with due respect and shall take all appropriate steps to prevent any attack in his person, freedom or dignity." Seorang agen diplomatik tidak dapat diganggu gugat. la tidak dapat dipertanggungjawabkan dalam segala bentuk penangkapan atau penahanan. Negara penerima harus memperlakukannya dengan penuh hormat dan harus mengambil setiap langkah yang diperlukan untuk mencegah adanya serangan terhadap diri sendiri, kemerdekaan dan martabat. $^{8}$

Perlindungan ini juga dilengkapi dengan jaminan kebebasan bergerak dan berpergian di wilayah negara penerima seperti yang disebutkan dalam Pasal 26 adalah merupakan kewajiban pemerintah di negara akreditasi

\footnotetext{
7 "Duta Besar Indonesia di Myanmar akui adanya penyadapan"

https://nasional.tempo.co/read/44939/duta-besar-

indonesia-di-myanmar-akui-adanya-penyadapan

8 Lihat Pasal 29 Konvensi Wina 1961.
} 
mengambil semua tindakan yang diperlukan untuk melindungi pejabat diplomatik dari tindakan kekerasan. ${ }^{9}$

Dalam pasal 29 menunjukan bahwa negara penerima pun memiliki kewajiban untuk melindungi para diplomat yang ada di negaranya dengan cara sebagaimana yang dijelaskan. Hal ini juga sejalan dengan prinsip kesepakatan bersama (mutual consent) dan prinsip resiprositas atau timbal balik bahwa masing-masing negara pun ingin agar para diplomatnya sendiri aman di negara mereka ditugaskan serta menjaga hubungan yang telah ada. ${ }^{10}$

Kemudian hak kekebalan dari pejabat diplomatik terdapat kekebalan yuridiksional, akibat yang paling penting tidak boleh diganggu gugatnya seorang diplomatik adalah hak untuk bebas dari yuridiksi negara penerima sehubungan dengan masalah-masalah kriminal. Dapatlah dikatakan bahwa kekebalan para diplomat bersifat mutlak dan dalam keadaan apapun mereka tidak boleh diadili ataupun dihukum. Bila seorang diplomat melakukan tindakan kriminal di negara akreditasi, tentunya tergantung dari pemerintah atau kepala perwakilannya untuk menanggalkan kekebalan diplomatik seorang diplomat. ${ }^{11}$

Dalam Konvensi Wina 1961 juga mengatur tentang hak-hak istimewa dan kekebalan anggota keluarga pejabat diplomatik, Pasal 37 menyatakan bahwa "the members of family of a diplomatic agent forming part of his household shall, if they are not nationals of the receiving state, enjoy the privileges and immunities specified in articles 29 to 36." Anggota keluarga dari seorang wakil diplomatik yang merupakan bagian dari rumah tangganya, yang bukan berwarga negara negara penerima akan menikmati hak-hak istimewa dan kekebalan sebagaimana diatur dalam pasal 29 sampai $26 .{ }^{12}$

Seperti juga halnya dengan kantor-kantor perwakilan, terdapat dua aspek dari kekebalan yaitu kewajiban negara penerima untuk tidak melakukan hak-hak berdaulat terutama hakhak penegakan hukum dan kewajiban untuk

\footnotetext{
${ }^{9}$ Boer Mauna, Op. cit, hlm 504.

10 Setyo Widagdo dan Hanif Nur Widhiyanti, Op. cit. hlm 189.

11 Lihat Pasal 32 Konvensi Wina 1961

12 Lihat Pasal 37 Konvensi Wina 1961.
}

memperlakukan para pejabat diplomatik dengan hormat dan melindungi mereka dari gangguan orang-orang lain serta gangguan terhadap kebebasan dan martabat mereka. ${ }^{13}$

Aturan terhadap perwakilan diplomatik juga termasuk perlindungan terhadap gedung perwakilan yang diatur dalam Pasal 22 ayat 2 Konvensi Wina 1961, yaitu : "The receiving state is under a special duty to take all appropriate steps to protect the premises of the mission against any intrusion or damage and to prevent any disturbance of the peace of the mission or impairment of its dignity." Negara penerima mempunyai kewajiban khusus untuk mengambil langkah yang patut untuk melindungi wisma-wisma perwakilan dari setiap gangguan atau kerusakan dan mencegah setiap gangguan ketenangan perwakilan atau hal yang merugikan martabat perwakilan diplomatik. ${ }^{14}$

Tidak diganggu-gugatnya gedung perwakilan asing suatu negara pada hakikatnya menyangkut dua aspek. Aspek pertama adalah mengenai kewajiban negara penerima untuk memberikan perlindungan sepenuhnya sebagai perwakilan asing di negara tersebut dari setiap gangguan. Bahkan bila terjadi keadaan luar biasa seperti putusnya hubungan diplomatik atau terjadinya konflik bersenjata antara negara pengirim dan negara penerima, kewajiban negara pnerima untuk melindungi gedung perwakilan berikut harta milik dan arsip-arsip tetap harus dilakukan. Aspek kedua, adalah kedudukan perwakilan asing itu sendiri yang dinyatakan kebal dari pemeriksaan termasuk barang-barang miliknya dan semua arsip-arsip. ${ }^{15}$

Konvensi Wina 1961 dalam Pasal 34, seorang pejabat diplomatik akan dibebaskan dari semua pungutan dan pajak-pajak, baik pajak barang bergerak maupun barang tidak begerak, pajak pusat, daerah dan kotapraja, kecuali :

a) Pajak-pajak tidak langsung dari suatu barang yang biasanya telah dimasukkan dalam harga barang atau jasa;

b) Pungutan dan pajak-pajak atas harta milik pribadi tidak bergerak, yang terletak di wilayah negara

\footnotetext{
13 Boer Mauna, Op.cit., hlm 504.

14 Lihat Pasal 22 Konvensi Wina 1961.

${ }^{15}$ Sumaryo Suryokusumo, Op.cit., hlm 148.
} 
penerima, kecuali yang dikuasainya atas nama negara pengirim atau untuk keperluan perwakilan;

c) Pajak-pajak tanah milik, suksesi atau warisan yang dikenakan oleh negara penerima, tunduk pada ketentuan dari ayat 4 pasal 39;

d) Pungutan dan pajak atas penghasilan pribadi yang bersumber di negara penerima dan pajak atas modal yang ditanamkan dalam usaha-usaha perniagaan dalam negara penerima;

e) Biaya yang dipungut atas jasa-jasa khusus yang diterimanya;

f) Biaya-biaya pendaftaran, pengadilan atau pencatatan, hipotik dan bea materai untuk harta milik tidak bergerak, tunduk pada ketentuan-ketentuan pasal 23. ${ }^{16}$

\section{Konvensi Wina 1963 tentang Hubungan Konsuler}

Dalam Pasal 7 Konvensi Wina 1963 tentang hubungan konsuler menyebutkan bahwa suatu perwakilan konsuler yang berada di suatu negara bertugas untuk menjalankan fungsifungsi konsuler. Dibukanya suatu perwakilan konsuler karena negara pengirim menganggap perlu dibentuknya perwakilan konsuler mengingat kepentingan negaranya dan warga negaranya.

Dalam menjalankan tugas dan fungsinya sebagai perwakilan konsuler di suatu negara, para perwakilan konsuler juga berhak untuk mendapatkan hak kekebalan dan keistimewaan sebagai penunjang dan jaminan untuk mereka bertugas dengan lancar dan mempermudah kegiatan mereka di negara penerima.

Hak kekebalan dan keistimewaan perwakilan konsuler seperti yang tercantum dalam Konvensi Wina 1963, sebagai berikut :

1. Kekebalan kantor konsuler

2. Kekebalan alat komunikasi dan kekebalan berkomunikasi

3. Kekebalan pribadi pejabat konsuler

4. Kekebalan fiskal

5. Pembebasan pembayaran pajak pribadi

6. Pembebasan bea masuk

Perlindungan tentang Perwakilan Konsuler diatur dalam Pasal 31 ayat 3, yaitu “... the

\footnotetext{
16 Lihat Pasal 34 Konvensi Wina 1961.
}

receiving state is under a special duty to take all appropriate steps to protect the consular premises against any intrusion or damage and to prevent any disturbance of the peace of the consular post or impairment of its dignity." Negara penerima mempunyai kewajiban khusus untuk mengambil langkah yang patut untuk melindungi wisma-wisma konsuler dari setiap gangguan atau pengrusakan dan mencegah setiap gangguan ketenangan atau yang merugikan martabat perwakilan konsuler. ${ }^{17}$

Dalam Pasal 40 Konvensi Wina 1963 juga dicantumkan perlindungan terhadap pejabat konsuler : "the receiving state shall treat consular officers with due respect and shall take all appropriate steps to prevent any attack in their person, freedom or dignity." Negara penerima harus memperlakukan pejabat konsuler dengan penuh hormat dan harus mengambil langkah yang patut untuk mencegah setiap serangan atas diri pribadinya, kebebasan dan martabatnya. ${ }^{18}$

Hak kekebalan dan keistimewaan juga berlaku terhadap pejabat konsuler di saat pejabat konsuler menjalankan tugas dan fungsinya. Dan negera penerima berkewajiban untuk menjamin dan melindungi hak kekebalan dan istimewa dari pejabat konsuler.

\section{B. Pertanggungjawaban Negara Terhadap Pejabat Diplomatik yang Mendapat Ancaman di Negara Penerima}

Sering tindakan yang diambil oleh suatu negara menimbulkan luka atau penghinaan atas, martabat atau kewajiban negara lain. Kaidah-kaidah hukum internasional mengenai tanggung jawab negara menyangkut keadaankeadaan di mana, dan prinsip-prinsip dengan mana, negara yang dirugikan menjadi berhak atas ganti rugi untuk kerugian yang dideritanya. Tanggung jawab negara telah dinyatakan secara tegas dibatasi pada "pertanggungjawaban negara-negara bagi tindakan-tindakan yang secara internasional tidak sah". ${ }^{19}$

Prinsip kedaulatan negara dalam hubungan internasional sangatlah dominan. Negara berdaulat mempunyai kedaulatan yang satu tidak tunduk pada negara berdaulat yang lain. Negara mempunyai kedaulatan penuh atas

\footnotetext{
17 Lihat Pasal 31 Konvensi Wina 1963

18 Lihat Pasal 40 Konvensi Wina 1963

19 J.G Starke, Op.cit., hlm 391.
} 
orang, barang dan perbuatan teritorialnya. Meskipun demikian, tidaklah berarti bahwa negara dapat menggunakan kedualatan itu seenaknya sendiri. Hukum internasional telah mengatur bahwa di dalam kedaulatan terkait di dalamnya kewajiban untuk tidak menyalahgunakan kedaulatan tersebut. Karenanya, suatu negara dapat dimintai pertanggungjawaban untuk tindakan-tindakan atau kelalaiannya yang melawan hukum. ${ }^{20}$

Pertanggungjawaban negara berhubungan erat dengan suatu keadaan terhadap prinsip fundamental dari hukum internasional, yaitu negara atau suatu pihak yang dirugikan berhak untuk mendapatkan ganti rugi atas kerugian yang dideritanya. ${ }^{21}$ Dalam interaksinya satu sama lain amat besar kemungkinannya negara membuat kesalahan ataupun pelanggaran yang merugikan negara lain, di sinilah muncul pertanggungjawaban negara tersebut. Setiap pelanggaran terhadap hak negara lain menyebabkan negara tersebut wajib untuk memperbaikinya atau dengan kata lain mempertanggungjawabkannya. ${ }^{22}$ Suatu negara dikatakan bertanggungjawab dalam hal, negara tersebut melakukan pelanggaran atas perjanjian internasional, melanggar kedaulatan wilayah negara lain, menyerang negara lain, mencederai perwakilan diplomatik negara lain, bahkan memperlakukan warga asing dengan seenaknya. Oleh karena itu, pertanggungjawaban negara berbeda-beda kadarnya tergantung pada kewajiban yang diembannya atau besar kerugian yang telah ditimbulkan. ${ }^{23}$

Dalam hukum internasional dikenal dengan adanya dua macam aturan, primary rules dan secondary rules. Primary rules adalah seperangkat aturan yang mendefinisikan hak dan kewajiban negara yang tertuang dalam bentuk traktat, hukum kebiasaan atau instrumen lainnya. Secondary rules adalah seperangkat aturan yang mendefinisikan bagaimana dan apa akibat hukum apabila primary rules itu dilanggar oleh negara.

\footnotetext{
20 Sefriani, Op.cit., hlm. 253

21 Yudha B. Ardhiwisastra, Hukum Internasional Bunga Rampai, Alumni, Bandung, 2003, hlm 4.

22 Sefriani, Op.cit., hlm 254.

23 Jawahir Thontowi dan Pranoto Iskandar, Op.cit., hlm 194.
}

Secondary rules inilah yang disebut hukum tanggung jawab negara. ${ }^{24}$

Persoalan tentang prinsip-prinsip umum bagi pertanggungjawaban negara telah menjadi tugas bagi The International Law Commision (ILC) untuk dituangkan dalam sebuah instrumen hukum. ILC dalam kaitan dengan tugas tersebut mengeluarkan The ILC Draft Articles mengenai pertanggungjawaban negara. ${ }^{25}$ Rumusan yang dikeluarkan oleh International Law Commision (ILC) merupakan usaha yang sangat berarti dalam memperlengkapi hukum diplomatik. ${ }^{26}$ Karakteristik esensial dari pertanggungjawaban tergantung pada beberapa faktor. Pertama terdapatnya eksistensi akan terdapatnya sebuah kewajiban internasional. Kedua, telah terjadinya sebuah tindakan (commission) atau kelalaian (omission) yang menyebabkan terjadinya pelanggaran. Dan terakhir adalah terdapatnya kerugian yang diakibat oleh tindakan yang melawan hukum. ${ }^{27}$ Hakim Huber menyatakan bahwa, pertanggungjawaban merupakan ikutan dari sebuah hak. Semua hak yang memiliki karakter internasional mengandung kewajiban internasional pula. Pertanggungjawaban mengakibatkan kewajiban untuk melakukan perbaikan (reparasi) dalam kewajiban yang dimaksud tidak dilaksanakan. ${ }^{28}$

Dalam Pasal 1 Draft State responsibility for Internationally Wrongful Acts 2001 menyatakan bahwa "Every internationally wrongful act of a State entails the Internasional responsibility of that State." setiap internationally wrongful act yang dilakukan suatu negara, menimbulkan tanggung jawab internasional terhadap negara tersebut. ${ }^{29}$

Sehubungan dengan meningkatnya pelanggaran-pelanggaran terhadap misi atau staf diplomatik, pada tahun 1981 Majelis Umum PBB telah mengeluarkan resolusi yang meminta kepada negara-negara anggota untuk memberitahukan kepada Sekretaris Jenderal mengenai tindakan-tindakan terorisme yang dilakukan terhadap misi atau staf diplomatik.

\footnotetext{
${ }^{24}$ Sefriani, Op.cit., hlm 254.

25 Jawahir Thontowi dan Pranoto Iskandar, Op.cit., hlm 197.

${ }^{26}$ Sumaryo Suryokusumo, Op.cit., hlm 40.

27 Jawahir Thontowi dan Pranoto Iskandar, Op.cit., hlm 197.

28 Ibid.

29 Lihat Pasal 1 Draft articles on Responsibility of States for Internationally Wrongful Acts, ILC, 2001.
} 
Resolusi tersebut juga minta kepada segenap anggota PBB agar melaporkan tindakantindakan apa yang telah dilakukan untuk menghukum para pelanggar termasuk usaha pencegahan agar tidak lagi terjadi antara lain melalui sanksi-sanksi. Negara-negara anggota juga diminta untuk memberikan pandangan mereka mengenai langkah-langkah yang akan diambil di masa mendatang untuk melindungi wakil-wakil diplomatik dan termasuk perwakilannya. ${ }^{30}$

Setiap internationally wrongful acts negara menimbulkan tanggung jawab negara. Tindakan berbuat atau tidak berbuat (omission) dari negara dapat merupakan internationally wrongful acts yang mengandung dua unsur yaitu:

1. Dapat dilimpahkan pada negara berdasarkan hukum internasional;

2. Merupakan pelanggaran kewajiban terhadap hukum internasional (breach of an international obligation). ${ }^{31}$

Tanggung jawab negara juga berkaitan dengan teori kesalahan, dalam hukum internasional terdapat dua macam teori kesalahan negara yang membahas tentang apakah tanggung jawab negara terhadap tindakannya yang melanggar hukum atau kelalaiannya itu mutlak atau apakah perlu adanya pembuktian kesalahan niat atau kehendak dari tindakan pejabat atau agen negara. ${ }^{32}$ Terdapat dua teori kesalahan diantaranya adalah :

1. Teori objektif, Menurut teori ini tanggung jawab adalah mutlak. Menurut teori ini manakala suatu pejabat atau agen negara telah melakukan tindakan yang mengakibatkan kerugian terhadap orang lain, maka negaranya bertanggung jawab menurut hukum internasional tanpa dibuktikan apakah tindakan tersebut dilaksanakan dengan maksud baik atau jahat. Dalam teori ini tidak di pertimbangkan unsur suatu perbuatan.

2. Teori Subjektif, Menurut teori ini tanggung jawab negara ditentukan oleh adanya unsur kesalahan (dolus) atau

\footnotetext{
${ }^{30}$ Sumaryo Suryokusumo, Op. cit. hlm 40

${ }^{31}$ Sefriani, Op.cit.. hlm 256.

32 Huala Adolf, Aspek Aspek Negara dalam Hukum Internasional, RajaGrafindo, Jakarta, 1996, hIm 187.
}

kelalaian (culpa) pada pejabat atau agen negara yang bersangkutan. ${ }^{33}$

Maka menurut teori tersebut, jika terjadi ancaman atau pelanggaran terhadap pejabat diplomatik, negara penerima bertanggungjawab mutlak atas kesalahan tersebut, seperti yang telah disebutkan dalam pasal 29 Konvensi Wina 1961.

Merupakan suatu bentuk pelanggaran terhadap Konvensi Wina 1961, disaat negara penerima gagal untuk memberikan perlindungan terhadap para perwakilan diplomatik yang telah menjalankan tugas dan fungsinya. Maka negara penerima berhak untuk bertanggung jawab atas segala yang telah dialami oleh negara pengirim, negara pengirim juga bertanggung jawab untuk melakukan perbaikan terhadap kerugian yang di akibatkan oleh negara penerima dalam segala bentuk.

Dalam Draft ILC, dengan jelas menunjuk siapa yang dapat mengajukan pertanggungjawaban. Pertama, pasal 42 yang menggunakan istilah 'injured state' atau sebagai negara yang terugikan. Penggunaan istilah injured state ini merupakan analogi dari pasal 60 ayat 2 VCLT. Dan yang kedua adalah pasal 48 yang menunjuk pada komunitas internasional secara keseluruhan. Pengertian kewajiban erga omnes oleh pengadilan dinyatakan sebagai 'sebagaimana dicerminkan sifat alamiahnya merupakan persoalan bersama (by their very nature they are the concern of all states. In view of the importance of the rights involved, all States can be held to have legal interest in their protection... $)^{\prime} .^{34}$

Kemudian bentuk tanggung jawab negara penerima terhadap pelanggaran yang telah dilakukan, berdasarkan Draft ILC 2001, sebagai berikut :

1. Pasal 30 (Cessation and non-repetition)

" The state responsible for the internationally wrongful act is under an obligation :

a) to cease that act, if it is continuing;

b) to offer appropriate assurancces and guarantees of non-repetition, if circumstances so require."

Berdasarkan pasal 30 huruf $b$, bentuk tanggung jawab yang dapat dilakukan

\footnotetext{
33 Ibid.

34 Jawahir Thontowi dan Pranoto Iskandar, Op.cit, hlm 203.
} 
negara penerima adalah memberi jaminan terhadap negara pengirim bahwa pelanggaran terhadap negara pengirim tidak akan terjadi lagi. Dengan diberikan jaminan tersebut maka akan menimbulkan rasa aman bagi negara pengirim untuk melaksanakan tugas dan fungsi sebagai perwakilan diplomatik.

2. Pasal 31 (Reparation)

1) The responsible state is under an obligation to make full reparation for the injury caused by the internationally wrongful act.

2) Injury includes any damage, wheter material or moral, caused by the internationally wrongfull act of a State.

Berdasarkan pasal 31, negara penerima bertanggungjawab untuk memberikan reparasi penuh terhadap negara pengirim terhadap kerugian yang dialami, baik itu dalam bentuk materil atau moral, tergantung dari kejadian yang dialami

3. Pasal 34 (Forms of Reparation)

"Full reparation for the injury caused by the internationally wrongful act shall take the form of restitution, compensation and satisfaction, either singly or in combination, in accordance with the provions of this chapter."

Berdasarkan pasal 34, reparasi penuh yang dimaksud terdiri dari resutition, compensation dan satisfaction. Bentuk tanggungjawab yang dapat dilakukan tergantung dari kerugian yang dialami.

4. Pasal 37 (Satisfaction)

1) The State responsible for an internationally wrongful act is under an obligation to give satisfaction for the injury caused by that act insofar as it cannot be made good by restitution or compensation.

2) Satisfaction may consist in an acknowledgement of the breach, an expression of regret, a formal apology or another appropriate modality.

3) Satisfaction shall not be out to the injury and may not take a form humiliating to the responsible State.

Berdasarkan Pasal 37, Satisfaction yang dimaksud adalah pengakuan atas pelanggaran, ekspresi penyesalan, permintaan maaf resmi atau cara lain yang sesuai.
Dengan adanya bentuk tanggung jawab seperti yang telah tercantum dalam Draft articles on Responsibility of States for Internationally Wrongful Acts, ILC 2001, maka suatu bentuk kewajiban bagi suatu negara pengirim yang telah lalai atau gagal untuk melindungi para perwakilan diplomatik di negaranya untuk dapat bertanggung jawab atas segala bentuk pelanggaran yang dialami.

Seperti halnya, disaat terjadi kasus penyadapan di Kedutaan Besar Republik Indonesia (KBRI) di Yangon, Myanmar. Pada saat itu Myanmar selaku negara penerima yang berkewajiban untuk menjaga dan melindungi perwakilan diplomatik di negaranya sesuai dengan Konvensi Wina 1961, tetapi disitu Myanmar telah mencederai Konvensi Wina sendiri dengan melakukan penyadapan terhadap gedung perwakilan Indonesia. Maka dari itu, Myanmar sebagai negara penerima berhak untuk bertanggung jawab atas kegagalan untuk memberikan perlindungan terhadap kekebalan dan keistimewaan diplomatik terhadap perwakilan diplomatik Indonesia, seperti bentuk tanggung jawab yang telah tercantum dalam draft ILC 2001. Dengan adanya bentuk pertanggungjawaban dari Myanmar sebagai negara yang bertanggungjawab adanya kasus yang menimpa pihak Indonesia, akan terbentuk suatu hubungan yang baik antara kedua negara tersebut dan negara-negara yang mengadakan hubungan diplomatik dengan Myanmar akan merasa aman.

Pun juga, disaat terjadi hal yang demikian, negara penerima harus memberikan perlindungan dan keamanan terhadap hak kekebalan diplomatik terhadap perwakilan diplomatik negara pengirim. Namun, jka terjadi kasus ancaman atau terror terhadap para perwakilan diplomatik di Negara penerima, Negara penerima harus bertanggungjawab atas ancaman dan teror karena negara-negara tersebut sudah menyetujui adanya Perjanjian Internasional yang mengatur negara-negara tersebut, seperti yang telah tercantum dalam Hukum Internasional atas hal tersebut. Kemudian dengan adanya bentuk tanggung jawab akan tercipta adanya keseimbangan dan hubungan baik antar negara penerima dan negara pengirim. 


\section{PENUTUP}

\section{A. Kesimpulan}

1. Pelanggaran terhadap pejabat diplomatik sangat marak terjadi, baik itu ancaman maupun terorisme. Padahal, para pejabat diplomatik mempunyai tugas yang sangat berat dalam hal menjalin hubungan dan menjadi perwakilan bagi negaranya di negara penerima. Untuk itu diperlukan sebuah instrumen hukum sebagai bentuk perlindungan terhadap para perwakilan diplomatik di negara penerima. Dalam hukum internasional pun telah mengatur adanya aturan-aturan berupa konvensi tentang perlindungan terhadap perwakilan diplomatik maupun konsuler. Konvensi-konvensi tersebut yaitu, Konvensi Wina 1961 tentang Hubungan Diplomatik dan Konvensi Wina 1963 tentang Hubungan Konsuler. Dalam konvensi-konvensi tersebut telah berisi tentang bagaimana hak kekebalan dan keistimewaan dari perwakilan diplomatik dan konsuler itu sendiri.

2. Sebagai negara penerima memiliki kewajiban untuk menjamin adanya keselamatan dan serta melindungi para perwakilan diplomatik di negaranya, sesuai dengan yang telah tercantum dalam Konvensi Wina Pasal 29. Namun jika terjadi pelanggaran atau ancaman terhadap perwakilan diplomatik di negara penerima, sebagai Negara penerima harusnya bertanggungjawab penuh atas pelanggaran yang terjadi terhadap para pejabat diplomatik di negaranya. Dan bentuk tanggung jawab terhadap pelanggaran yang terjadi dapat dilihat sesuai dengan Draft ILC 2001 yaitu, Reparation (perbaikan), Compensation (kompensasi), Restitution (restitusi) dan Satisfaction (pemuasaan).

\section{B. Saran}

1. Sebagai Negara penerima (receiving state) harus menjaga hubungan baik dengan Negara pengirim (sending state), yaitu dengan menjaga dan melindungi keamanan perwakilan diplomatik yang ada di negaranya dari segala macam ancaman. Dan juga sebagai negara penerima harus menaati apa yang telah tertuang di dalam Konvensi Wina. Dengan hal demikian, para pejabat diplomatik yang berada di negara penerima bisa menjalankan tugas dan fungsinya dengan baik dikarenakan telah merasa aman dan dilindungi. Maka tidak akan terjadi insiden yang dapat membahayakan para pejabat diplomatik.

2. Negara penerima (receiving state) harus bertanggung penuh atas segala ancaman dan pelanggaran yang terjadi terhadap para perwakilan diplomatik. Kemudian diperlukan sebuah upaya untuk membuat ketentuan yang lebih tegas dan ketat mengenai pertanggungjawaban negara terhadap tindakan yang merugikan negara lain. Agar bisa meminimalisir ancaman dan pelanggaran yang terjadi terhadap para pejabat diplomatik di negara pengirim.

\section{DAFTAR PUSTAKA}

Adolf, Huala. Aspek Aspek Negara dalam Hukum Internasional, RajaGrafindo, Jakarta, 1996.

Ardhiwisastra, Yudha B. Hukum Internasional Bunga Rampai, Alumni, Bandung, 2003.

Dembinski, L. The Modern Law of Diplomacy, Martinus Nijhoff Publishers, Netherlands, 1988.

Denza, Eileen. Diplomatic Law, Commentary on the Vienna Convention on Diplomatic Relations, Oceania Publication, Inc. Dobbs Ferry, New York, 1976 dikutip dalam buku Sumaryo Suryokusumo, Hukum Diplomatik dan Konsuler, PT Tatanusa, Jakarta, 2013.

Effendi, A. Masyhur. Hukum Konsuler - Hukum Diplomatik serta Hak dan Kewajiban Wakil - Wakil Organisasi Internasional/Negara, IKIP Malang, Malang, 1994.

Kindred, Hugh M. International Law Chiefly as Interpreted and Applied in Canada, Emond Montgomery Publications Limited, Canada, 1987.

Kusumaatmadja, Mochtar. Pengantar Hukum Internasional, Buku I: Bagian Umum, PT Binacipta, Bandung, 1982. dan Etty R. Agoes, Pengantar Hukum Internasional, Edisi ke-2, PT Alumni, Bandung, 2010. 
Mauna, Boer. Hukum Internasional: Pengertian Peranan Dan Fungsi Dalam Era Dinamka Global, PT Alumni, Bandung, 2001.

Noor S.M., Birkah Latif dan Kadarudin. Hukum Diplomatik dan Hubungan Internasiona, Pustaka Pena Press, Makassar, 2016.

Pakenham, Gore-Booth, D. Satow's Guide to Diplomacy Practice, Fifth Edition, Logman Group Ltd, London, 1979.

Parthiana, I Wayan. Pengantar Hukum Internasional, Mandar Maju, Bandung, 2003.

Rudy, T. May. Hukum Internasional 2, PT Refika Aditama, Bandung, 2011.

Sefriani. Hukum Internasional Suatu Pengantar Edisi Kedua, Rajawali Pers, Jakarta, 2017.

Sen, B. A Diplomat's Handbook of International Law and Practice, Martinus Nijhoff publishers, Den Haag, 1979.

Soekanto Soerjono dan Sri Mamudji. Penelitian Hukum Normatif, RajaGrafindo, Jakarta, 2009.

Starke, J.G. Pengantar Hukum Internasional Edisi Kesepuluh, Sinar Grafika, Jakarta, 1989.

Suryokusumo, Sumaryo. Hukum Diplomatik Teori dan Kasus, Alumni, Bandung, 1995.

Hukum Diplomatik dan Konsuler, PT Tatanusa, Jakarta, 2013.

Suryono Edy. Perkembangan Hukum Diplomatik, Mandar Maju, Bandung, 1992.

dan Moenir Arisoendha. Hukum Diplomatik Kekebalan dan Keistimewaanya, Angkasa, Bandung, 1991.

A.K, Syahmin. Hukum Diplomatik dalam Kerangka Studi Analisis. PT Rajagrafindo Persada, Jakarta, 2008.

Hukum Diplomatik Suatu Pengantar. CV Armico, Bandung, 1988.

Thontowi, Jawahir dan Pranoto Iskandar. Hukum Internasional Kontemporer, PT Refika Aditama, Bandung, 2006.

Widagdo, Setyo dan Hanif Nur W. Hukum Diplomatik dan Konsuler, Bayumedia Publishing, Malang, 2008.
Widodo. Hukum Diplomatik dan Konsuler Pada era Globalisasi, LaksBang Justitia, Surabaya, 2009.

\section{Sumber Lain :}

"Duta Besar Indonesia di Myanmar akui adanya penyadapan" https://nasional.tempo.co/read/44939/ duta-besar-indonesia-di-myanmar-akuiadanya-penyadapan

"Duta Besar Rusia untuk Turki tewas di Ankara" https://www.bbc.com/indonesia/dunia -38373034, diakses pada 11 september 2019

Draft articles on Responsibility of States for Internationally Wrongful Acts, ILC, 2001.

Vienna Convention On Diplomatic, 1961.

Vienna Convention On Diplomatic, 1963.

Statuta Mahkamah Internasional 